\title{
Development and validation of an analytical method for the extraction and quantification of soluble sulfates in red clay
}

\section{(Desenvolvimento e validação de um método analítico para a extração e quantificação de sulfatos solúveis em argilas vermelhas)}

\author{
V. I. Cáceres ${ }^{1}$, J. S. Molina ${ }^{1}$, A. L. C. García ${ }^{2}$ \\ ${ }^{1}$ Centre of Investigation of Ceramic Materials, Group of Investigation in Ceramic Technology GITEC, \\ Francisco de Paula Santander University, Cúcuta, Norte de Santander, Colombia \\ ${ }^{2}$ Group of Investigation in Natural Resources, University of Pamplona, Pamplona, Norte de Santander Colombia \\ isel1302@gmail.com,j_sanchezmolina@yahoo.es, achaparro@unipamplona.edu.co
}

\begin{abstract}
In this work a fast and environmentally friendly method for the extraction and quantification of soluble sulphates in red clay using microwave assisted extraction (MAE) and determination by turbidimetry was developed and validated. The favorable conditions for the extraction of soluble sulphates in red clay by MAE were: $1 \mathrm{~g}$ of sample, with particle size of $63 \mu \mathrm{m}$, dissolved in $50 \mathrm{~mL}$ of distilled water, it was extracted using a microwave oven with $70 \%$ of power during $5 \mathrm{~min}$, later the sample was centrifuged during $5 \mathrm{~min}$ and then filtered. The soluble sulphates in red clays were quantified at $420 \mathrm{~nm}$. The procedure proposed showed linear behaviour in the tested rank (5-7000 $\mathrm{mg} \mathrm{SO}_{4}^{2-} / \mathrm{kg}$ of clay) with $\mathrm{R}^{2} 0.9993$. The limits of detection and quantification were 4.30 and $14.33 \mathrm{mg} / \mathrm{kg}$, respectively, with a variation coefficient of $1.41 \%$. The method proposed in this work allows to determine soluble sulphates in red clay with a recovery of $94 \%$.
\end{abstract}

Keywords: red clay, soluble sulphates, microwave assisted extraction (MAE), turbidimetry.

\section{Resumo}

Neste trabalho foi desenvolvido e validado um método rápido e inofensivo ao ambiente para a extração e quantificação de sulfatos solúveis em argilas vermelhas usando extração assistida por microondas (MAE) e determinação por turbidimetria. As condições favoráveis para a extração de sulfatos solúveis de argilas vermelhas por MAE foram: $1 \mathrm{~g}$ de amostra, com tamanho de partícula de $63 \mu \mathrm{m}$, dissolvido em $50 \mathrm{~mL}$ de água destilada, foi extraida em um forno micro-ondas a 70\% de potência durante 5 min e então filtrada. Os sulfatos solúveis em argilas vermelhas foram quantificados em $420 \mathrm{~nm}$. O procedimento proposto apresentou comportamento linear na faixa testada (5-7000 $\mathrm{mg} \mathrm{SO}_{4}^{2-} / \mathrm{kg}$ de argila), com $\mathrm{R}^{2}$ 0,9993. Os limites de detecção e de quantificação foram 4,30 e $14,33 \mathrm{mg} / \mathrm{kg}$, respectivamente, com um coeficiente de variação de 1,41\%. O método proposto neste trabalho permite determinar sulfatos solúveis em argila vermelho com uma recuperação de $94 \%$.

Palavras-chave: argila vermelha, sulfatos solúveis, extração assistida por micro-ondas (MAE), turbidimetria.

\section{INTRODUCTION}

Cúcuta and his surrounding areas are privileged for having clay formations of excellent quality, which has allowed to give origin to one of the most significant sectors of the region: the ceramic industry [1], conformed by 157 companies, of which 59 are legally established [2], all engaged to manufacturing clay-based products, standing out the construction materials, such as: ceramics, vitrified tablets, enameled tablets, knits, bricks, artisan products (decorations and veneers), among others [3], turning into one of the main alternative for the region development; this is why is the big importance of constantly improving the quality of the offered products with the intention of reaching the necessary competitivity to keep in the existing markets and enter into others international level [4].
In most cases, the ceramic materials for facade that are manufactured in the region, such as bricks, knits, tiles, etc., present efflorescences, fundamentally due to the migration of soluble salts like sulphates, nitrates and chlorides from different origins [5-9], which pose on the material surface in the form of stains, generally whitish [10-13]; this pathology makes the decrease of the aesthetic quality thereof, which means depretiation in the cost of the finished product, which leads to economic losses for entrepreneurs of the sector $[14,15]$.

From the above, is important to have faster and environmentally friendly analytical techniques that allow to control the presence of these salts in the raw materials to avoid the efflorescence in the finished products. In the last decade there has been an increasing demand for new extraction techniques, susceptible of automation, with 
shorter extraction times, reduced consumption of organic solvents and waste generation, pollution prevention inside the laboratories, decreasing the risks for the analysts, cost reduction in the sample preparation and that are environmentally friendly. Among this can be found the microwave assisted extraction (MAE), ultrasound assisted extraction (UAE), supercritic fluent extraction (SFE), etc. [16-19].

Microwave assisted extraction (MAE) are based on the use of the microwave energy to achieve that the compounds of interest pass from the sample to a suitable solvent. It is a fast technique that allows the control of a series of parameters that affect the extraction efficiency. The principle of heating using the microwave energy is based on the direct effect of the microwaves on the molecules by ionic driving and dipolar rotation. In several applications these two mechanisms take place simultaneously [16]. The capacity of a solvent to absorb energy from microwave and transmit it in the form of heat to other molecules, will depend partially on the dissipation factor [17].

There are different analytical methods for the determination and quantification of ions sulphates, such as the gravimetric method [20], volumetric method, spectrophotometric methods, ion selective electrode, ionic chromatography, capilar electroforesis, analysis by flow injection, among others [21, 22]; however they require long time and high operational costs, and some need qualified personnel [22].

Among the spectrophotometric methods used for the determination of ions sulphates the method of barium chloranilate, method of blue of metiltimol and the turbidimetric procedure of barium sulphate can be found [23]. The turbidimetric procedure have as a base the formation of particles of small size that cause the dispersion of the light when a source of radiation incide on such particles. The degree of dispersion of light (or turbidity of the solution) is proportional to the number of particles that find on its way, which depends on the quantity of analyte present in the sample. The turbidimetric determination of sulphate has advantanges such as simplicity, low requests for the instrumentation, robustness and rapidity [24, 25]. The sulphate ion has the peculiarity of precipitate from the barium chloride in acidic environment, forming a suspension of barium sulphate crystals of uniform size and appearance [24]. The absorbtion of the suspension is measured by spectrophotometry to $420 \mathrm{~nm}$ and the concentration of $\mathrm{SO}_{4}^{2-}$ is determined by interpolation of the curve of calibration, according to the normalized methods. The dissolved sulphates reacts in the filtered with the hydrochloric acid, forming sulphuric acid and chlorides; finally, when the barium chloride is added the barium sulphate is obtained, when remaining in suspension becomes white and as its concentration increases, the colour turns more pronunced. It requires an acidic environment to avoid the precipitation of the barium salts from anions, such as carbonate and phosphate. The co-precipitation of barium hydroxide is also prevented in slightly acid medium. The glycerin solution is required to modify the viscosity of the sample and thus allow the precipitated of barium sulphate to keep in homogeneous suspension during a period of time enough to measure its absorbance [25].

The turbidimetric methods require that the process for the suspension formation always be done under the same conditions; therefore, the speed and degree of formation, the stability and the optical qualities of the suspension are affected by the temperature of the solution, the acidity, the size of barium chloride granules and the quantity added, the time and speed of agitation, the time of rest of the suspension before the measurement and the presence of organic matter $[26,27]$.

Given the importance to study the soluble sulphates in the clays by his relation with the efflorescences and taking into account that the investigations about these in the clays are rare, in the present work an environmentally friendly method for the extraction and quantification of this analyte in red clays was developed and validated using MAE and turbidimetry techniques.

\section{EXPERIMENTAL}

\section{Instruments, material and reagents}

For this study the following analytical reagents grade were used: sodium sulphate, hydrochloric acid, sodium chloride, glycerin and barium chloride. Salt-Acid Reagent: was prepared taking $23.6 \mathrm{~mL} \mathrm{HCl}, 253.0 \mathrm{~g} \mathrm{NaCl}$, and diluted to $1 \mathrm{~L}$ with distilled water. The extraction was carried out in a domestic microwave oven: Haceb ASHM-1.1 Grill Inox. For the quantification of sulphates was used an UVVis photometer, single beam, Genesys 20, Thermo Scientific, range of wavelength 325 to $1100 \mathrm{~nm}$ with plastic cell of $1 \mathrm{~cm}$.

\section{Procedure and methodology}

All the analyses were carried out in triplicate.

Samples preparation procedure for the analysis of clay: the size to the samples was diminushed using a crusher of hammers to disintegrate the clods, and homogenized very well to not skew. Later the sample was powdered using a mini planetary mill of zirconium balls during 5 min at 500 $\mathrm{rpm}$, dried in a stove at $105^{\circ} \mathrm{C}$ during $24 \mathrm{~h}$ and conserved in the desiccator until the analysis.

Turbidimetric conditions: In order to select the most favorable turbidimetric conditions for the determination of soluble sulphates in clays, different wavelengths used in diverse studies were tested for the determination of sulphates by turbidimetry methods in matrices like water and soils [25-35]. Such conditions were tested and modified to obtain better results. The method of reference applied is described in the ASTM C867-94 (2007), which some conditions were modified. The procedure followed for the turbidimetric measures in the determination of soluble sulphates in clays was: the filtered obtained from the extraction was diluted to a final volume of $25 \mathrm{~mL}$ with distilled water, $5 \mathrm{~mL}$ of glycerin 
reactive and $2.5 \mathrm{~mL}$ of salt-acid reactive were added, it was agitated very well with a glass rod during $30 \mathrm{~s}$, the $\mathrm{pH}$ is measured, and the reading in the equipment was taken (cell of $1 \mathrm{~cm}$ ) to $420 \mathrm{~nm}$ and adjusting the absorbance to zero (blank), afterwards the content of the cell was added to the beaker of the solution and added $0.2 \mathrm{~g}$ of barium chloride of uniform size $(0.6 \mathrm{~mm})$, agitated until all the crystals dissolved, rested during $5 \mathrm{~min}$ and the absorbance of the sample was measured. To obtain reproducible results, it is indispensable to keep always the same order of addition of reagents and control rigorously the time passed between the barium chloride addition and the reading of absorbance [26, 27].

Development of the extraction method: with the intention to establish the best conditions for the extraction of the analyte from the matrix, a series of experiments were carried out employing the microwave assisted extraction (MAE). The parameters evaluated were solvent volume $(20,30,40$ and $50 \mathrm{~mL}$ of distilled water), sample size (1, 2 and $3 \mathrm{~g}$ ), power of the microwave oven $(50,60,70,80,90$ and $100 \%$ ), extraction time (4, 5, 6 and $10 \mathrm{~min})$ and particle size $(63,75,150,180$ and $250 \mu \mathrm{m})$. The distilled water was used as extracting agent, since it is not contaminant and the sulphates dissolve easily; different studies have shown that the water is the most efficient dissolvent of extraction of soils [36]. Besides the water is a very polar molecule, that is able to absorb the energy of microwaves and to dissipate it in the form of heat [17]. To establish the parameters of extraction of the method, it was used a sample of clay contaminated with sulphates previously analysed by Ingeominas, which this designated R2, from the Ladrillera Saint Carlos of the city of Roldanillo, Cauca Valley, Colombia.

Processing of data: Taking into account the relation between the curve of calibration and the law of Beer, the concentration of soluble sulphates in clays was determined in the following way $[26,27,35]$ : using the equation of the straight line (Equation A) and the value of the absorbance obtained for each filtered analysed, the concentration of sulphates was determined (Equation B).

$$
y=b x+a
$$

where $\mathrm{y}$ is the absorbance, $\mathrm{x}$ the concentration, $\mathrm{b}$ the slope and a the ordinate at the origin.

$$
\mathrm{x}=\frac{\mathrm{y}-\mathrm{a}}{\mathrm{b}}=\frac{\mathrm{mg}}{\mathrm{kg}} \text { sulphate }=\frac{\mathrm{mg} \text { sulphate }}{\mathrm{kg} \text { clay }}
$$

The factor water/solids was determined taking into account the volume of water and the quantity of clay, used for the extraction (Equation C).

$$
\frac{\mathrm{mL} \text { water }}{\mathrm{g} \text { clay }}=\frac{\mathrm{g} \text { water }}{\mathrm{g} \text { clay }}=\frac{\mathrm{kg} \text { water }\left(\mathrm{g} \times 10^{-3}\right)}{\mathrm{kg} \text { clay }\left(\mathrm{g} \times 10^{-3}\right)}
$$

The volume of water can be converted to mass, using the density of the water $1 \mathrm{~g} / \mathrm{mL}$. The filtered obtained of the extraction has to be diluted to a fixed volume, of this volume an aliquot of $25 \mathrm{~mL}$ of sample is taken, which will be used for the analysis (Equation D); therefore, this factor has to be taken into account, to determine the concentration of sulphates in the complete sample.

$$
\frac{\text { Vol. Final }}{\text { Vol. aliquot }}=\frac{\text { Vol. Final }}{25 \mathrm{~mL}}
$$

Based on the previous, the concentration of sulphates in the sample of clay will be (Equation E):

$$
\begin{aligned}
& \frac{\mathrm{mg} \text { of sulphate }}{\mathrm{kg} \text { of clay }}=[\text { sulphate }] \text { curve calibracion } \\
& \mathrm{x} \frac{\mathrm{mg} \text { sulphate }}{\mathrm{kg} \text { clay }} \times \frac{\mathrm{kg} \text { water }}{\mathrm{kg} \text { clay }} \times \frac{\text { Vol. Final }(\mathrm{mL})}{25 \mathrm{~mL}}
\end{aligned}
$$

When the concentration of sulphates exceeds the limits of linearity, that is, the absorbance is higher than 1 , the law of Beer does not complies as it only works for diluted solutions, converting the straight line into a curve. The reading of absorbance out of the limits of linearity translates in a false concentration; in this situation, it is necessary to dilute the sample so that its concentration go in the limits of the linearity.

Validation of the proposed method: the method was validated for analysis of soluble sulphates in samples of red clay evaluating the linearity, the limit of detection, the limit of quantification, the precision and the accuracy, starting from these conditions more favourable for the extraction of soluble sulphates in red clays by MAE and later quantification by turbidimetry. The linearity of the method was evaluated using 8 different concentrations of the sulphate ion in the rank $0-140 \mathrm{mg} / \mathrm{kg}$; the concentrations used were $0,20,40$, $60,80,100,120$ and $140 \mathrm{mg} / \mathrm{kg}$.

\section{RESULTS AND DISCUSSION}

\section{Particle size}

The effect that the clay sample particle size has in the extraction of soluble sulphates was evaluated; the conditions of extraction were: $1 \mathrm{~g}$ of clay, $50 \mathrm{~mL}$ of distilled water, 5 min of time of extraction and $50 \%$ power of the microwave oven. The results are shown in Fig. 1.

From Fig. 1 it can be observed that as the solute particle size becomes smaller, extraction of soluble sulphates is greater. This behaviour is due to that when decreasing the size of particle, will increase the surface of contact between the solute and the dissolvent, and as consequence will increase the possibility of crashes between the particles, increasing the speed of dissolution. The reduction of the particles size also influences on solubility, increasing it when the size of the sample decreases. However, the incidence of this increase of solubility is smaller compared to the one of the surface of contact by decreasing the particle size, since 


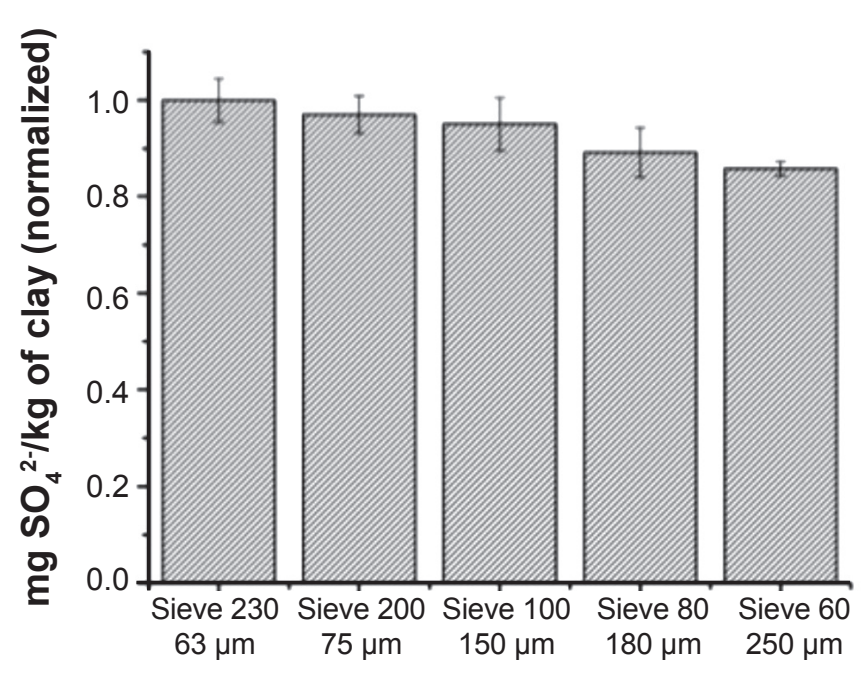

Particle size

Figure 1: Efficiency of extraction of soluble sulphates in red clays, using different particle sizes.

[Figura 1: Eficiência de extração de sulfatos solúveis em argilas vermelhas, utilizando diferentes tamanhos de partícula.]

the smaller particles quickly dissolve. Therefore, the sample particle size that favours the extraction of soluble sulphates in clays was of $63 \mu \mathrm{m}$ or lower (mesh ASTM 230).

\section{Sample amount and solvent volume}

The effect that the sample amount and the solvent volume heve in the extraction of soluble sulphates was evaluated; the conditions of extraction were 5 min of extraction time, $50 \%$ power of the microwave oven and particle size $63 \mu \mathrm{m}$. The results obtained are shown in Fig. 2.

From Fig. 2 it can be deduced that the clay sample more diluted is the one that extracts larger quantity of soluble sulphates. In MAE it is required that the volume of the solvent be sufficient to ensure that all the sample dissolve. During the extractions it was observed that when using 3 $\mathrm{g}$ of clay in $20 \mathrm{~mL}$ of distilled water, the sample formed a very dense slip, making it impossible to vary the extraction time and the power of the microwave oven because the sample was dried; but when the extractions were done using less quantity of clay in more volume of solvent, the sample remained much more diluted. This phenomenon can be explained if one considers that for a solute to be dissolved in a liquid it is necessary that the second first molecules disintegrate and facilitate its solvation in this way; this process depends on the dielectric constant of the solvent and the polarity of the molecules of the solute and the solvent [16]. The more polar nature of the solute, the higher force of attraction between the molecules and therefore higher resistance to disintegration; in order to decrease the attraction constant it is necessary to resort to using solvents of high dielectric constant [17]. Therefore, the volume of solvent and amount of the sample that favours the extraction of soluble sulphates in clays is 50 $\mathrm{mL}$ of distilled water and $1 \mathrm{~g}$ of clay.

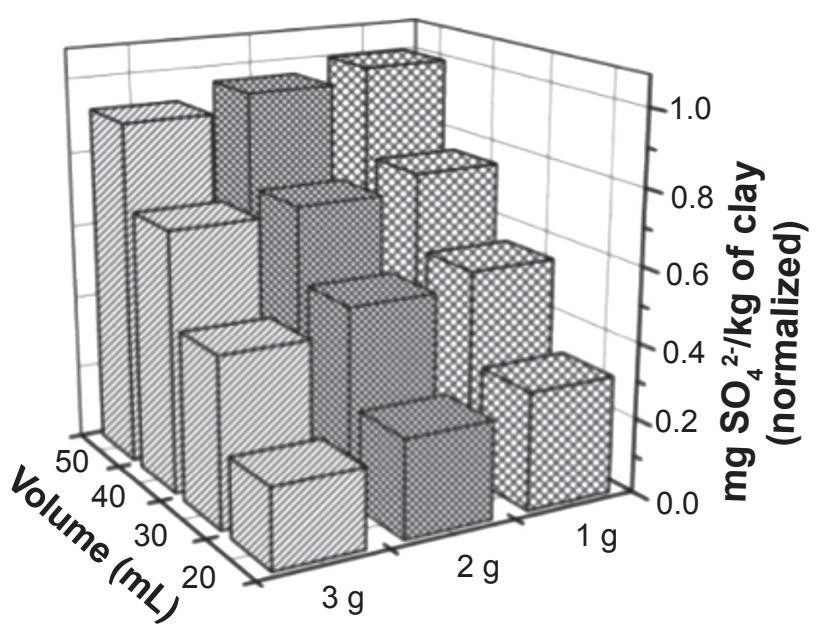

Figure 2: Efficiency of extraction of soluble sulphates in red clay, using different sample amount and solvent volumes.

[Figura 2: Eficiência de extração de sulfatos solúveis em argila vermelha, usando diferentes quantidades de amostra e volumes de solvente.]

\section{Microwave oven power and extraction time}

The most investigated parameter in MAE is the extraction temperature, which is not surprising since the temperature is an important factor that contributes to the increase of the recovery of the analyte, no only for MAE but for all the extraction techniques [17]. With MAE, temperatures above the boiling-point of the solvent may be achieved. High temperatures can produce efficient and improved extraction, since the desorption of the analytes of active sites can increase. Additionally, the solvents are more able to solubilize the analytes at high temperatures, while the surface tension and viscosity of the solvent decreases with temperature, sample wetting and penetration of the matrix is improved, respectively [17]. The times of extraction in MAE are very short compared to the conventional techniques; when an oven without control of temperature is used, as it is the case of the domestic microwave ovens, it has to optimise the power of the oven, with the intention of choosing the best time of extraction so that it reaches the sufficient temperature, and then obtain an efficient extraction. The power is the speed which electrical energy turns into another form of energy, for the case of MAE the electrical energy, is transformed in microwave radiation by means of the magnetron; the power of the microwave oven used was $1400 \mathrm{~W}$. The effect that has the extraction time and the power of the microwave oven in the extraction of soluble sulphates was evaluated; different tests were performed varying the time (5 and 10 min) and the power $(50,60,70,80,90$ and $100 \%)$, being found that the lower the extraction time the greater amount of analyte is obtained; likewise, worth to mention that when increasing the power of the microwave oven, the concentration of sulphates decreased; due to that as the power is increased, the volume of the filtered obtained of 


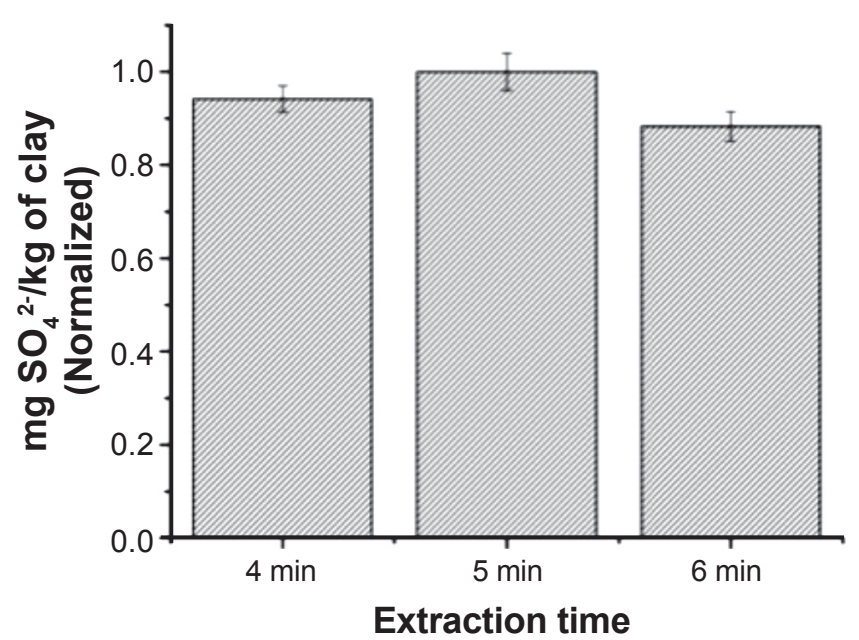

Figure 3: Efficiency of extraction of soluble sulphates in clays, using different time of extraction.

[Figura 3: Eficiência de extração de sulfatos solúveis em argilas, utilizando diferentes tempos de extração.]

the extraction decreased, because the temperature began to increase as the dissolvent of the sample evaporated. To rule out the possibility that more extraction times would lower the amount of the analyte to be extracted, the extraction time was varied taking into account the results obtained previously; the conditions of extraction were $50 \%$ power of the microwave oven, size of particle $63 \mu \mathrm{m}, 1 \mathrm{~g}$ of sample and $50 \mathrm{~mL}$ of solvent. The results obtained are shown in the Fig. 3, where the time that produced better results in the extraction of soluble sulphates in clays was $5 \mathrm{~min}$.

In the test of the variables performed earlier, the filtered obtained of each extraction was taken to a constant volume of $50 \mathrm{~mL}$ diluited with distilled water, in order to make the analyses under the same conditions. The volume $\sim 38.5 \mathrm{~mL}$ of the filtered was obtained under the following conditions of extraction: size of particle mesh ASTM 230, volume of solvent $50 \mathrm{~mL}$ of distilled water, amount of sample $1 \mathrm{~g}$ of clay, time of extraction $5 \mathrm{~min}$ and $50 \%$ of power of the microwave oven. With the intention to decrease the volume of the filtered to an equal or lower volume to $25 \mathrm{~mL}$, which is volume required to make the analysis by turbidimetry, the power of the microwave oven was varied. According to the results and analysis obtained previously to optimise the power of the microwave oven, can be deduced that when increasing the power, the volume of filtered decreases. Therefore, the power of the oven was varied in the $60-90 \%$ range; the conditions of extraction were $5 \mathrm{~min}$ of time of extraction, size of particle $63 \mu \mathrm{m}, 1 \mathrm{~g}$ of sample, $50 \mathrm{~mL}$ of solvent and volume of the end of the filtered $25 \mathrm{~mL}$. The results are shown in Fig. 4.

It can be deduced that when using $70 \%$ of the power of the microwave oven, larger quantity of analyte is extracted, as long as the filtered reaches $25 \mathrm{~mL}$. The volume of filtered of the extraction obteined with $70 \%$ power of the microwave oven, produced roughly $23.8 \mathrm{~mL}$; therefore, little water

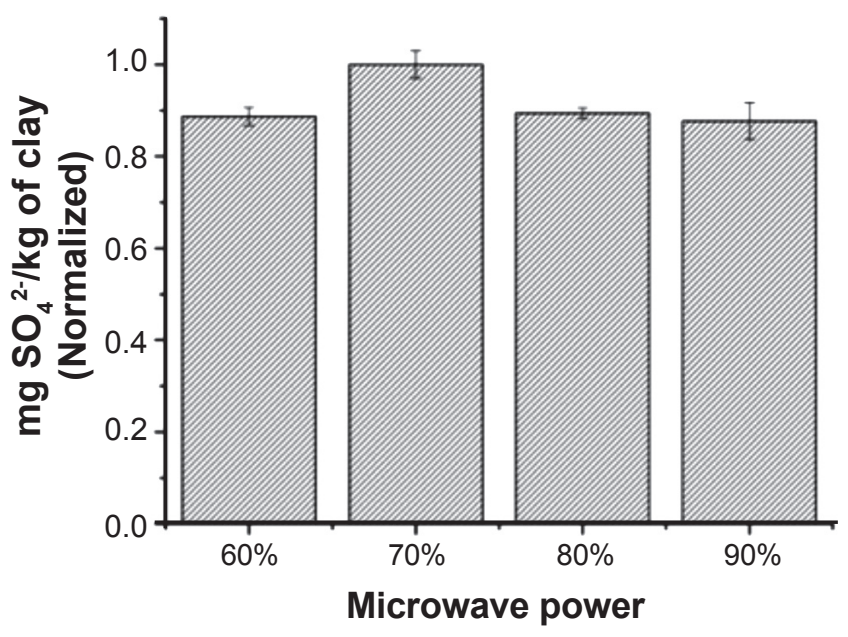

Figure 4: Efficiency of extraction of soluble sulphates in clays, using different levels of power of the microwave oven.

[Figura 4: Eficiência de extracção de sulfatos solúveis em argilas, utilizando diferentes níveis de potência do forno micro-ondas.]

was added to the filtered to complete the volume of $25 \mathrm{~mL}$ required for the back analysis. One of the advantages to use MAE is the reduction of the time of extraction when microwaves are appliedç this can be due mainly to the difference in the performance of heating employed by the microwaves technique and the conventional heating. In the conventional heating it is required a certain time to heat the container of extraction and later transfer the heat to the solution, whereas the microwaves heat directly the sample; this keeps the gradient of temperature to a minimum and accelerates the rate of heating. The capacity of quickly heating the mixture sample-solvent is inherent to MAE and is the main advantage of this technique. The disadvantages or inconvenient that presents MAE are: the dissolvent that is used in the extraction has to absorb the energy of microwaves, except if the matrix contains water and, the degradation of thermally labile compounds. The times of extraction of the different methods of extraction for sulphates in samples of soils that can be found [8, 26, 27, 33-36, 42-44] goes from $22 \mathrm{~h}$ to $15 \mathrm{~min}$, therefore, are greater in comparison to the method of extraction by MAE developed in this work that is $5 \mathrm{~min}$, the time is a very important and significant variable when it has to analyse hundreds of samples. The use of distilled water as solvent involves the saving of reagents and therefore, decrease of costs in the extraction. Besides they do not generate wastes contaminants, what means the method of extraction by MAE for soluble sulphates in clays developed in this work is effective, reproducible, fast, economic and environmentally friendly.

\section{Validation of the method proposed}

The most favourable conditions for the extraction of soluble sulphates in red clays, by MAE are: size of particle of the sample $63 \mu \mathrm{m}$, quantity of sample $1 \mathrm{~g}$, volume of the 
Table I - Data of validation for the method MAETurbidimetry.

[Tabela I - Dados de validação do método MAETurbidimetria.]

\begin{tabular}{|c|c|}
\hline Parameter & Value \\
\hline Equation & $y=5.781 \times 10^{-3} x+7.33 \times 10^{-3}$ \\
\hline $\begin{array}{l}\text { Squared of the correlation } \\
\text { coefficient }\left(\mathrm{R}^{2}\right)\end{array}$ & 0.9993 \\
\hline Slope & $5.781 \times 10^{-3}$ \\
\hline Ordered in the origin & $7.33 \times 10^{-3}$ \\
\hline $\begin{array}{l}\text { Linear rank of } \\
\text { the solution }(\mathrm{mg} / \mathrm{kg})\end{array}$ & $0-140$ \\
\hline $\begin{array}{l}\text { Linear rank for the clays } \\
\left(\mathrm{mg} \mathrm{SO}_{4}{ }^{2-} / \mathrm{kg} \text { clay) }\right.\end{array}$ & $5-7000$ \\
\hline $\mathrm{LOD}\left(\mathrm{mg} \mathrm{SO}_{4}^{2-/ k g}\right.$ clay) & 4.30 \\
\hline LOQ (mg $\mathrm{SO}_{4}^{2-/ k g ~ c l a y) ~}$ & 14.33 \\
\hline Recovery & $94 \%$ \\
\hline Coefficient of variation & $1.41 \%$ \\
\hline
\end{tabular}

solvent $50 \mathrm{~mL}$ of distilled water, time of extraction $5 \mathrm{~min}$ and power of the microwave oven $70 \%$. The filtered obtained of the extraction by MAE has to gauge until complete a volume of $25 \mathrm{~mL}$ and, later has to analyse and determine the concentration of soluble sulphates in clays by turbidimetry. To evaluate the performance of the MAE-Turbidimetry, the parameters were measured using clay from the surrounding areas of Cúcuta North of Santander, Colombia, with known concentration of sulphates. The parameters of validation are presented in the Table I. Each analysis was done in triplicate.

Evaluation of the linearity and of the sensitivity of the method: a correlation coefficient $\left(\mathrm{R}^{2}\right)$ that exhibits a good linearity in the rank of examined concentrations was obtained; taking into account the calibration curve and the factor waters/solid, the procedure proposed showed a linear behavior in the rank $5-7000 \mathrm{mg} \mathrm{SO}_{4}^{2-} / \mathrm{kg}$ of clay.

Limit of detection (LOD) and limit of quantification (LOQ): The values calculated for LOD (proportion signal to noise of 3; $\mathrm{S} / \mathrm{N}=3$ ) and LOQ (proportion signal to noise of $10 ; \mathrm{S} / \mathrm{N}=10$ ) are shown in Table I.

Evaluation of the accuracy and precision: The evaluation of the accuracy of the method based in the recovery of quantities known of soluble sulphates in clays samples were evaluated for five different concentrations $(342.28 \mathrm{mg}$ $\mathrm{SO}_{4}^{2-} / \mathrm{kg}$ clay, $592.28 \mathrm{mg} \mathrm{SO}_{4}^{2-/} \mathrm{kg}$ clay, $3092.28 \mathrm{mg} \mathrm{SO}_{4}^{2-/}$ $\mathrm{kg}$ clay, $4592.28 \mathrm{mg} \mathrm{SO}_{4}^{2-} / \mathrm{kg}$ clay and $7092.28 \mathrm{mg} \mathrm{SO}_{4}^{2-/}$ $\mathrm{kg}$ clay), which were analysed according to the favourable conditions. The precision of the method was evaluated during a day and the values of repeatability were calculated analysing samples $(n=3)$ to the concentrations mentioned. The sulphates recovery values obtained and coefficient of variation (Table I) are considered suitable for the analysis of this analyte and show that the reproducibility of this method is satisfactory. Therefore, use it in the analysis of soluble sulphates in samples of red clays is suitable.

Comparison between the method extraction developed and a classical method for the extraction of soluble sulphates in clays

The method developed by microwave assisted extraction was compared to the extraction method [33] and the quantification was carried out by turbidimetry. In the Table II the results obtained are shown.

From Table II it can be deduced that the results obtained por the two methods differ in $0.08 \%$, that is negligible; but it is important to mention that the necessary time to carry out the extraction by the method reported [33], it is extensive (40 min). However, the microwave extraction is very fast (5 min); therefore, the method developed for the extraction of soluble sulphates in clays using radiation microwaves is very effective, generates reproducible results and, the most important, the time of extraction is very short.

Table II - Results of sulphates for the sample R2 analysed by extraction by MAE and the classical method [33], and back quantification by turbidimetry.

[Tabela II - Resultados dos sulfatos para a amostra R2 analisada por extração MAE e pelo método clássico [33], e posterior quantificação por turbidimetria.]

\begin{tabular}{|c|c|c|}
\hline Sample & $\begin{array}{c}\mathrm{mg} \mathrm{SO}_{4}{ }^{2-} / \mathrm{kg} \text { of clay } \mathrm{X}_{\mathrm{o}} \pm \mathrm{t}_{(\mathrm{n}-2)} \mathrm{Sx}_{\mathrm{o}} \\
{[33]}\end{array}$ & $\begin{array}{c}\mathrm{mg} \mathrm{SO}_{4}^{2-/} / \mathrm{kg} \text { of clay } \mathrm{X}_{\mathrm{o}} \pm \mathrm{t}_{(\mathrm{n}-2)} \mathrm{Sx}_{\mathrm{o}} \\
\text { Method MAE }\end{array}$ \\
\hline $\mathrm{R} 2$ & $3211.73 \pm 2.38$ & $3214.58 \pm 2.38$ \\
\hline
\end{tabular}

Table III - Results of sulphates for the sample R2 analysed by gravimetric and turbidimetri methods. [Tabela III - Resultados dos sulfatos para a amostra R2 analisada pelos métodos gravimétrico e turbidimétrico.]

\begin{tabular}{|c|c|c|}
\hline Sample & $\begin{array}{c}\text { gravimetric method } \\
\mathrm{mg} \mathrm{SO}_{4}^{2-/} \mathrm{kg} \text { of clay } \mathrm{X}_{\mathrm{or}} \pm \mathrm{t}_{(\mathrm{n}-2)} \mathrm{Sx}_{\mathrm{or}}\end{array}$ & $\begin{array}{c}\text { turbidimetric method } \\
\mathrm{mg} \mathrm{SO}_{4}^{2-} / \mathrm{kg} \text { of clay } \mathrm{X}_{\mathrm{or}} \pm \mathrm{t}_{(\mathrm{n}-2)} \mathrm{Sx}_{\mathrm{or}}\end{array}$ \\
\hline $\mathrm{R} 2$ & $3180.64 \pm 2.38$ & $3214.58 \pm 2.38$ \\
\hline
\end{tabular}


Comparison between the turbidimetric method and gravimetric for the quantification of soluble sulphates in clays

Two extractions of sulphates were made from the sample R2 by the method of extraction developed in this work. One of the filtered obtained of the extraction was quantified by turbidimetry and the another filtered quantified by gravimetry the methodology proposed by the Spanish norm UNE 77048:2002 [20]. In the Table III the results obtained are shown.

From Table III it can be deduced that the results obtained by the two methods differ in $1.05 \%$, that is negligible; it is worth to mention that the necessary time to carry out the determination by gravimetry is extensive ( 5 to $6 \mathrm{~h}$ ) since it treats of tedious essays that involves high manipulation of the sample. However, by means of turbidimetry, the process of analysis is very fast ( 8 to $10 \mathrm{~min}$ ) generating reproducible results.

\section{CONCLUSIONS}

The methodology used for the extraction and quantification of soluble sulphates in red clays validated in this work, fulfils with the parameters demanded for the validation of an analytical method, assuring this way that the results obtained when applying them in the analysis of red clays are reliable. The method for extraction of soluble sulphates in clays developed by MAE in this work is effective, reproducible, fast, economic and environmentally friendly; it showed to surpass a lot of inherent limitations to each one of the conventional methods reported for this analysis. Contrary to others methods of extraction of soluble sulphates in clays that with frequency are wasteful, contaminant and require an enormous amouny of time and expenses to analize.

\section{ACKNOWLEDGEMENTS}

This work has been funded by the Centre of Investigation of Ceramic Materials - CIMAC of the Francisco de Paula Santander University. The authors express gratitude to the CIMAC and to the University of Pamplona by the support offered for the realisation of the essays.

\section{REFERENCES}

[1] J. Sánchez, "Conformación e Implementación del Clúster de la Cerámica", Cong. Bras. Ceram., Salvador, BA, Brazil (2007) 51.

[2] E. J. Prato, "Planteamiento de modelos productivos para la estandarización de los procesos de producción de las mipymes del sector cerámico del área metropolitana de san José de Cúcuta", Tesis de Pregrado en Ingeniería de Producción Industrial, Universidad Francisco de Paula Santander, Colombia (2007).

[3] J. F. Gélves, R. Monroy, J. Sánchez, R. P. Ramírez,
"Estudio comparativo de las técnicas de extrusión y prensado como procesos de conformado de productos cerámicos de construcción en el Área Metropolitana de Cúcuta", Bol. Soc. Esp. Ceram. Vidr. 52, 1 (2013) 48-54.

[4] J. Sánchez, R. Monroy, "Clúster de la Cerámica en Norte de Santander una opción para el Desarrollo Regional", Universidad Francisco de Paula Santander, Colombia (2007).

[5] R. M. Esbert, J. Ordaz, F. Alonso, M. Montoto, Manual de Diagnosis y Tratamiento de Materiales Pétreos y Cerámicos. Col.legi d'Aparelladors i Arquitectes pétreos y cerámicos, Tècnics de Barcelona, Barcelona, España (1997) 97-99.

[6] R. Kozikowski, P. Taylor, M. Macgregor, Development of Accelerated Test Method for Measuring and Minimizing Efflorescence Potential, Portland Cement Assoc. - PCA R\&D, Serial No. 2515b (2007).

[7] L. Pel, H. Huinink, K. Kopinga, R. Van, O. Adan, "Efflorescence pathway diagram: understanding salt weathering", Constr. Building Mater. 18 (2004) 309-313.

[8] J. Ma. Rincón, M. Romero, "Prevención y eliminación de eflorescencias en la restauración de ladrillos de construcción”, Materiales de Construcción 51, 261 (2001) 73-78.

[9] M. Macgregor, J. Melander, "Efflorescence a Synopsis of the Literature", North American Masonry Conf., Clemson, South Carolina, USA (2003).

[10] C. Ferreira, C. Bergmann, "Transport of $\mathrm{Ca}^{2+}$ and $\mathrm{SO}_{4}{ }^{2-}$ ions in Porous Media of Clay Product and its Association with the Efflorescence Phenomenon", Transp. Porous Med. 86 (2011) 1-12.

[11] J. Osuna, "Estudio general sobre las eflorescencias en obra", Madrid, Spain (1998).

[12] H. Brocken, T. Nijland, "White efflorescence on brick masonry and concrete masonry blocks, with special emphasis on sulfate efflorescence on concrete blocks", Constr. Building Mater. 18 (2004) 315-323.

[13] P. Russell, "Efflorescence and the discoloration of concrete", Taylor \& Francis, ISBN 0-203-97502-2 (2005).

[14] M. F. Gazulla, M. Gómez, M. Orduña, S. Vicente, J. Arorós, "Determinación de sales solubles y eflorescencias en tejas cerámicas", Bol. Soc. Esp. Ceram. Vid. 49, 3 (2010) 189-196.

[15]J.Ma. Rincón, M. Romero, "Fundamentos y clasificación de las eflorescencias en ladrillos de construcción", Materiales de Construcción 50, 260 (2000) 63-69.

[16] J. Soriano, Microtoxinas en alimentos, Ediciones Díaz de Santos, Spain, ISBN 978-84-7978-808-7 (2007) 99.

[17] C. Sparr, E. Björklund, "Analytical - scale microwave asisted extraction", J. Chromatography A 902 (2002) 227 250.

[18] S. Koning, H. Janssen, U. Brinkman, "Review: Modern Methods of Sample Preparation for GC Analysis", Chromatographia Suppl. 69 (2009) S33-S78.

[19] R. Azuola, P. Vargas, "Extracción de sustancias asistida por ultrasonido (EAU)", Tecnología en Marcha 20, 4 (2007) 30-40. 
[20] Norma Española UNE 77048: "Calidad del agua. Determinación de sulfatos. Método gravimétrico" (2002).

[21] S. K. Verma, M. K. Deb, "Direct and rapid determination of sulphate in environmental samples with diffuse reflectance Fourier transform infrared spectroscopy using $\mathrm{KBr}$ substrate", Talanta 71 (2007) 1546-1552.

[22] Y. S. Fung, C. Wong, J. Choy, K. Sze, "Determination of sulfate in water by flow-injection analysis with electrodeseparated piezoelectric quartz crystal sensor", Sensors Actuators B 130 (2008) 551-560.

[23] J. F. Van, R. E. Taljaard, "Determination of sulphate in natural waters and industrial effluents by sequential injection analysis", Analyt. Chim. Acta 331 (1996) 271-280.

[24] S. Meneses, N. Maniasso, E. Zagatto, "Spectrophotometric flow-injection determination of sulphate in soil solutions", Talanta 65 (2005) 1313-1317.

[25] C. A. Severiche, H. González, "Evaluación analítica para la determinación de sulfatos en aguas por método turbidimétrico modificado', Ing. USBMed 3, 2 (2012) 6-11. [26] S. Combs, J. Denning, K. Frank, "Sulfate-Sulfur. Recommended Chemical Soil Test Procedures for the North Central Region", North Central Regional Res. Publ. 221, 8 (2011) 35-39.

[27] R. Singh, D. Bhumbla, R. Keefer, "Recommended Soil Sulfate-S Tests. Recommended Soil Testing Procedures for the Northeastern United States", $3^{\text {rd }}$ Ed., Northeastern Regional Publ. 493, 7 (2011) 55-61.

[28] Instituto Colombiano de Normas Técnicas y Certificación. Norma Técnica Colombiana NTC 4708, Calidad del Agua: Determinación de Sulfato $\left(\mathrm{SO}_{4}^{-2}\right)$ Método Turbidimétrico, Bogotá, Colombia (1999).

[29] A. Pisal, "Water and Environmental Analysis: Determination of Sulfate", Turbidimetric Method 375, 4 (2010) 46-51.

[30] L. Clesceri, A. Greenberg, R. Trussell, Métodos Normalizados para el análisis de aguas potables y residuales: Sulfatos - Método turbidimétrico, 17 Ed., Madrid: Ediciones Díaz de Santos ISBN 84-7978-031-2 (1992) 4:233-235.

[31] I. Morais, M. Souto, T. Lopes, A. Rangel, "Use of a single air segment to minimise dispersion and improve mixing in sequential injection: turbidimetric determination of sulphate in waters", Water Res. 37 (2003) 4243-4249.

[32] A. Kolmert, K. Wikström, K. Hallberg, "A fast and simple turbidimetric method for the determination of sulfate in sulfate-reducing bacterial cultures", J. Microbiol. Methods 41 (2000) 179-184.

[33] S. Ben, F. Elferjani, F. Haroun, F. Abdelnabi, "Determination of Available Nitrate, Phosphate and Sulfate in Soil Samples", Int. J. Pharm. Tech. Res. 1, 3 (2009) 598604.

[34] Estado de California, Departament of transportation engineering service center: Method of Testing Soils and Water for Sulfate Content, California Test 417 (1999).

[35] American Society for Testing and Materials ASTM C867-94: Standard Test Method for Soluble Sulfate in Ceramic Whiteware Clays (Photometric Method) (2007).

[36] S. Stanisic, L. Ignjatović, M. Stević, A. Đorđević, "A comparison of simple extraction procedures for the determination of inorganic anions in soil by ion chromatography", J. Serb. Chem. Soc. 76, 5 (2011) 769-780. [37] P. Nayak, y B. Singh, "Instrumental Characterization of Clay by XRF, XRD and FTIR", Indian Acad. Sci. 30, 3 (2007) 235-238.

[38] R. G. Wolff, "Structural Aspects of Kaolinite Using Infrared Absorption", Am. Mineralogist 48 (1963) 390-399.

[39] B. Saikia, G. Parthasarathy, "Fourier Transform Infrared Spectroscopic Characterization of Kaolinite from Assam and Meghalaya, Northeastern India”, J. Mod. Phys. 1 (2010) 206-210.

[40] B. Davarcioglu, "Investigation of Central Anatolian region Nigde-Dikilitas (Turkey) clays by FTIR spectroscopy", Épitöanyag 62, 2 (2010) 55-60.

[41] T. Bruno, P. Svoronos, Handbook of Basic Tables for Chemical Analysis: Infrared Spectrophotometry, $3^{\text {rd }}$ Ed. Estados Unidos: Taylor \& Francis Group ISBN 978-1-42008042-1 (2011) 437-441.

[42] N. San Martin, H. Echeverria, "Sulfato en Suelos del Sudeste Bonarense", Ciencia del suelo 13 (1995) 95-97.

[43] D. Russi, F. Gutierrez Boem, P. Prystupa, G. Rubio, "Comparación de mediciones turbidimétricas de sulfatos utilizando distintos extractantes y tratamiento del extracto", Cong. Arg. Ciencia del Suelo, Rosario, Argentina (2010).

[44] E. Combatt, V. Álvarez, A. Dos Santos Ferreira, "Dosagem de sulfato por turbidimetria em solos tiomórficos", Acta Agronómica 63, 1 (2014) 1-7.

(Rec. 15/04/2015, Ac. 30/05/2015) 